\title{
THE RELATIONSHEEP OF AMINO ACID METABOLISM WITH PRODUCTIVITY OF GROWING YOUNG SHEEP
}

Ismail Sagidovich ISMAILOV, Department of Private Animal Husbandry, Breeding and Animal Breeding, Federal State Budgetary Educational Institution Stavropol State Agrarian University, ovcevodstvo_@ mail.ru

Nina Vladimirovna TREGUBOVA, Department Commodity Research and Technology of Public Catering, Belgorod University of cooperation, Economics and Law,Stavropol, tregubova_nina@mail.ru (corresponding author)

Rashid Hasanbievich KOCHKAROV, Department Commodity Research and Technology of Public Catering, Belgorod University of cooperation, Economics and Law,Stavropol, Stavropol, k.rash65@ yandex.ru

Anna Victorovna MORGUNOVA, Department Commodity Research and Technology of Public Catering, Belgorod University of cooperation, Economics and Law,Stavropol, Stavropol, hrynya@mail.ru

Natalija Alecseevna DRIZHD, Department Commodity Research and Technology of Public Catering, Belgorod University of cooperation, Economics and Law,Stavropol, Stavropol, drigdgl@yandex.ru

A number of studies on digestion of the ruminants have shown the process of synthesis of all the essential amino acids in the rumen (Abu Fadel, 2004; Trukhachev, V., Zlidnev, N. 2008). However, according to some researches, microbial protein is deficient in methionine and lysine. This assumption also proves the need for further study of the influence of balanced amino acids to these diets on the growth, development and productive performance of the ruminants.

Scientific approbation of the issues related to establishing the requirements of young sheep in lysine and methionine with cystine and development of recommendations for their proper balance in animal rations have been conducted along with a series of physiological, scientific and practical experiments. For this purpose, we used the following research methods: preparative, analytical, measuring and calculating. Zootechnical evaluation of young sheep's diet with different levels of lysine and methionine with cysteine has been conducted, and influence of these components on growth, development, metabolism, the use of amino acids and wool productivity have been studied.

The importance of studying the content of amino acids in plasma is evident because they are the indicators of protein metabolism in the animals' organism and represent themselves the exchange fund when used in the biochemical transformations in the process of updating the protein of the body tissues and the synthesis of animal products.

Increase in young sheep's diet of lysine and methionine can improve their productivity, reduce the cost of feed energy and improve biochemical indexes of meat, taking into account the optimization of its amino acid composition. Efficiency increase of young sheep during the process of the individual development is linked to conditions of feeding and in particular the usefulness of a protein food, which is primarily determined by sufficient intake of essential amino acids - lysine and methionine with cystine.

Thus, the inclusion in the diet of growing young sheep some amount of synthetic amino acids $-6-8$ grams of lysine and 3-4 g of methionine per 1 fodder unit, enhances oxidation-reduction processes, increase productivity, i.e. wool yield and other indicators.

The content of free amino acids in plasma directly depends on their availability in feed. The use of synthetic amino acids (lysine, methionine and cystine) contributed to the increase of their content in a free state in the blood serum, indicating their increased demand in sheep.

With the use of different doses of synthetic amino acids (lysine, methionine, cystine) in the diets of young sheep it has been found that the organization of optimum conditions of feeding, care and management of sheep in winter season help to avoid abrupt changes in the structure of the skin, to ensure the normal development of the histological structure and morphogenetic processes.)

Keywords: amino acid metabolism, young sheep, diet, productivity

\section{INTRODUCTION}

From the scientific works it is also known that the lack of one or several amino acids in the diet leads to disruption of protein synthesis, affects the health, productivity and reproductive ability of animals (Abu Fadel, 2004; Ismailov, I., Zhukov, L., Chabaev, I. 1991, Trukhachev, V., Zlidnev, N., Podkolzin A. 2009). In our opinion, this fact is the basis of the theory of balanced amino acid nutrition of animals in the organization of standardized and rational use of feed protein. Industrial production of synthetic amino acids and their rational, theoretically based use in the diets of farm animals is now seen as one of the most acute issues. The relevance of this problem emerges even more noticeable nowadays in connection with the rapid introduction of industrial production technology of livestock products. For the science and

Copyright (C) 2017 The Authors. Published by Aleksandras Stulginskis University. This is an open-access article distributed under the terms of the Creative Commons Attribution License (CC-BY 4.0), which permits unrestricted use, distribution, and reproduction in any medium, provided the original author and source are credited. 
practice of particular interest is the study and scientific rationale of the possibility and efficiency of use in the diets of young ruminants synthetic amino acids, production of which is established in the industrial way at the proper level.

The aim of the research is to determine the optimum level of lysine, methionine and cystine in the rations of young growth of sheep.

Objects of study are the sheep from 1 to 12 months of age.

\section{RESEARCH METHODS}

Research aimed at studying the influence of the full protein feeding on growth, development and productivity of the wool of young sheep. It was carried out by:

1. The experiments for the study of metabolism at young ewes of 6 months age by adding to the basic diet of the crystalline amino acids of lysine, methionine and cystine in various doses and ratios.

2. Carrying out biochemical blood tests to define the change in the composition of free amino acids in a protein-free blood filter using different doses of synthetic amino acids.

3. Defining of growth and development, as well as wool-growing of young sheep every two months until they reach the age of 12 months.

The research is based on young sheep of the planned fine-wool breeds reared in the Stavropol region ("the Caucasian" and "Soviet Merinos").

The scientific justification of amino acid norms of young sheep feeding was carried out by conducting feeding experiments on a group of pregnant and lactating ewes and lambs up to 12 months of age, and metabolism experiments on 6 months age ewes. During the experiment, lysine, methionine, cysteine have been added to the basic diet and hematological and biochemical studies have been carried out, and composition of free amino acids in a protein-free blood filtrate while adding of different doses of synthetic crystalline amino acid - lysine, methionine and cysteine - have been studied.

For the experiments on determining the composition of free amino acids in a protein-free blood filtrate, 10 groups of 3 lambs in each were formed. Control group of lambs received SSM (substitute of sheep milk) without supplements of amino acids. The experimental group of animals received SSM with supplements of amino acids (table 1).

Along with supplements in the form of synthetic amino acids, differentiation of diets on biological value and, in particular, on lysine content, was carried out due to combinations of various ratios of feed components.

Daily supplement of 2.5 grams of synthetic amino acid methionine (which provided 3.5-4.0 per cent of its content of crude protein) per head, contributed to the increase in wool yield of $688 \mathrm{~g}$, compared with a control group that did not receive the methionine supplement.

\section{RESEARCH RESULTS}

The concentration of free amino acids in blood of lambs of one month age are shown in table 1.

Table 1. Free amino acids of blood plasma, mg \% (age of lambs 1 month)

\begin{tabular}{l} 
Amino acids \\
\cline { 2 - 12 }
\end{tabular}

Analysis of table 1 shows that the number of free amino acids in the blood of the lambs is subjected to significant fluctuations. So, when increase in the diet proteins of lysine (experimental groups 1-3), its quantity in blood plasma increased by $17.55-24.20 \%$. In the presence of cystine and methionine clear pattern in the increase or decrease in this case couldn't be traced. 
The increase in the diet of methionine with cystine (groups 4-5) was accompanied by the decrease in the concentration of lysine in blood plasma by $6.39 ; 8.52 ; 4.26$. At the same time, the quantity of cystine increased by $10.88-18.13 \%$, and methionine decreased by $4.88 ; 7,32 ; 4.23 \%$.

Simultaneous application in the diet of lysine and methionine contributed to the increase of lysine in plasma by $19.68-28.46 \%$, cystine - by $19.17 ; 18.65 ; 20.21$ and methionine by $3.65-7.32 \%$.

The amount of essential and non-essential amino acids, and the ratio of nonessential to essential has changed at different levels of lysine and methionine in rations of the lambs.

The maximum amount of essential and non-essential amino acids in blood plasma was observed among lambs of the experimental group 8 .

As it was established in our early studies (Ismailov, I. 1968), the best results in weight gain, increase of wool yield were obtained with a simultaneous increase in diet of lysine and methionine up to $20 \%$ of crude protein. Thus, we aimed to verify these data on a large number of animals. Different lysine level was created through the use of concentrate feed lysine and methionine level - by the use of synthetic DL-methionine.

The feeding rations of young ewes from 6 to 12 months' age are presented in table 2 . Concentrate feed lysine (CCL) was added to the basic diet, taking into account that pure lysine additionally received was $1 \mathrm{~g}$ and $0.8 \mathrm{~g}$ of methionine.

Table 2. Feed rations of young ewes

\begin{tabular}{|c|c|c|c|c|}
\hline \multirow{3}{*}{ Indicators } & \multicolumn{4}{|c|}{ Age } \\
\hline & \multicolumn{2}{|c|}{ 6-8 months } & \multicolumn{2}{|c|}{$8-12$ monhs } \\
\hline & Normal & Content in the ration & Normal & Content in the ration \\
\hline 1 & 2 & 3 & 4 & 5 \\
\hline Hay, kg & - & 1.0 & - & 1.0 \\
\hline Corn silage, $\mathrm{kg}$ & - & 1.5 & - & 2.5 \\
\hline Bran cereal, kg & - & 0.14 & - & 0.15 \\
\hline Precipitate, $\mathrm{kg}$ & - & 0.007 & - & 0.01 \\
\hline Fodder unit & 0.85 & 0.98 & 1.05 & 1.1 \\
\hline Metabolizable energy, mj & 9.4 & 11.71 & 11.0 & 13.1 \\
\hline Dry matter, $\mathrm{kg}$ & 1.1 & 1.35 & 1.4 & 1.52 \\
\hline Crude protein, $\mathrm{g}$ & 145 & 164.3 & 180 & 180 \\
\hline Digestible protein, $\mathrm{g}$ & 100 & 107.6 & 110 & 116 \\
\hline Lysine, $\mathrm{g}$ & - & 6.61 & - & 7.01 \\
\hline Methionine with cystine, $\mathrm{g}$ & - & 5.10 & - & 5.58 \\
\hline Fiber, $\mathrm{g}$ & - & 379.1 & - & 447.9 \\
\hline Sugar, g & 80 & 54.5 & 88,0 & 58.5 \\
\hline Calcium, $\mathrm{g}$ & 5.0 & 8.34 & 6.4 & 9.1 \\
\hline Phosphorus, g & 3.4 & 3.3 & 4.1 & 4.1 \\
\hline Magnesium, g & 0.6 & 2.2 & 0.6 & 2.46 \\
\hline Sulfur, g & 3.0 & 3.42 & 3.7 & 3.94 \\
\hline Ferrum, mg & 45 & 360 & 49.0 & 391.5 \\
\hline Copper, mg & 8.0 & 5.68 & 8.1 & 6.25 \\
\hline Zinc, mg & 33.0 & 38.0 & 40.0 & 41.7 \\
\hline Cobalt, mg & 0.40 & 0.54 & 0.4 & 0.55 \\
\hline Manganese, mg & 45.0 & 145.9 & 52.0 & 149.5 \\
\hline Iodine, $\mathrm{mg}$ & 0.3 & 8.10 & 0.3 & 0.22 \\
\hline Carotene, $\mathrm{mg}$ & 7.0 & 70.0 & 8.0 & 81.0 \\
\hline Salt, g & 10.0 & 10.0 & 12.0 & 12.0 \\
\hline
\end{tabular}

Analyzing the data of the rations, it can be noted that at the age of 6 to 8 months' young ewes have received enough nutrients and bioactive substances. Lysine in the control group amounted 3.72 per cent from crude protein, methionine with cystine - 3.1 per cent. In the experimental group's ration due to the supplementation of $1 \mathrm{~g}$ of lysine and methionine, the lysine content was $4.6 \%$, methionine with cystine $-3.78 \%$. The contents in the diets of calcium, phosphorus, magnesium, sulfur, ferrum, copper, zinc, cobalt, manganese, iodine and carotene had no significant difference.

At the age of 8-12 months in the ration the level of lysine made up 3.89\%, methionine with cystine $3.1 \%$. Through supplementation of lysine and methionine up to 1 gram in the experimental group's diet, the level of lysine made up $4.45 \%$ of crude protein, methionine with cystine $-3.65 \%$.

During the research we have studied the productivity of young sheep (table. 3).

Table 3. Productivity of young sheep

\begin{tabular}{|l|c|c|c|c|c|c|}
\hline Group & $\begin{array}{c}\text { Live weight at } \\
\text { the age of } 6 \mathrm{~m} ., \\
\mathrm{kg}\end{array}$ & $\begin{array}{c}\text { Live weight at } \\
\text { the age of } 13 \\
\mathrm{~m} . \mathrm{kg}\end{array}$ & $\begin{array}{c}\text { Gain, } \\
\mathrm{kg}\end{array}$ & $\begin{array}{c}\text { Average daily } \\
\text { gain, g }\end{array}$ & $\begin{array}{c}\text { Costs of } 1 \mathrm{~kg} \text { of } \\
\text { live weight gain }\end{array}$ & $\begin{array}{c}\text { Costs of } 1 \mathrm{~kg} \\
\text { of wool gain }\end{array}$ \\
\hline 1 & 2 & 3 & 4 & 5 & 6 & 7 \\
\hline Control & 30.3 & 41.1 & 10.8 & 60.0 & 9.0 & 90.7 \\
\hline experimental & 31.4 & 43.3 & 11.9 & 66.1 & 8.3 & 84.8 \\
\hline
\end{tabular}


The table shows that live weight gain over 6 months in the control group was $10,8 \mathrm{~kg}$ and $11,9 \mathrm{~kg}$ in experimental group that is $10 \%$ higher. When calculating the costs of live weight gain it was found that in the experimental group they were on $7.8 \%$, lower and costs of wool gain were $6.7 \%$ lower.

One of the most important indicators of the productivity of fine-wool sheep is the number of wool yield in pure fiber. It is known that wool fibers after a thorough cleaning can be considered as consisting almost entirely of protein (keratin). The elemental composition of the keratin of wool according to (Ismailov, 1991, Selkin, 2011) consists of: carbon $-50.3-52.2 \%$, hydrogen $-6.4-7.3 \%$, nitrogen $-16.2-17.7 \%$, oxygen $-15-20.7 \%$ and sulfur -1 to $5 \%$.

The wool productivity of the animals of the experimental group was higher by $7.8 \%(\mathrm{P}<10,05)$. The increase in wool yield was due to more intensive hair growth in length and increase in its diameter.

The strength of fiber was better in the experimental group, too (tab. 4).

Table 4. Wool productivity of young sheep

\begin{tabular}{|l|c|c|c|c|c|}
\hline Group & \multicolumn{2}{|c|}{ Mass of wool in clean fiber, $\mathrm{kg}$} & $\begin{array}{c}\text { True length of hair, } \\
\mathrm{cm}\end{array}$ & $\begin{array}{c}\text { Wool thickness, } \\
\mathrm{mk}\end{array}$ & $\begin{array}{c}\text { Fortress of } \\
\text { breaking length }\end{array}$ \\
\hline \multicolumn{1}{|c|}{1} & 2 & 3 & 4 & 5 \\
\hline Control & 1.92 & 100 & 11.3 & 23.0 & 7.0 \\
\hline Experimental & 2.07 & 107.8 & 11.7 & 24.2 & 7.7 \\
\hline
\end{tabular}

Meat is one of the most important products of sheep breeding. The high profitability of the industry is only possible with the simultaneous production of wool and mutton.

It is known that mutton has excellent taste in protein, rich in essential amino acids, vitamins and minerals as beef, and in caloric content is even larger than beef ( $1 \mathrm{~kg}$ of beef contains 2300 calories $-9629 \mathrm{j}$. and $1 \mathrm{~kg}$ of mutton $2720 \mathrm{kcal}-11388 \mathrm{j})$. A distinctive feature of mutton is the low content of cholesterol $-290 \mathrm{mg} / \mathrm{kg}(750 \mathrm{mg} / \mathrm{kg} \mathrm{in} \mathrm{beef}$ and $745-1260 \mathrm{mg} / \mathrm{kg}$ in pork). Mutton is not peculiar in smell, which is provided by girsin acid.

Quantity and quality of meat products is in large degree influenced by the age of the sheep, their body type, feeding and management conditions (Konoplev, 2001; Tregubova, 2016).

Carcass weight of adult sheep depends on age, breed and fatness ranges from 18 to $30 \mathrm{~kg}$, the carcass weight of lambs at the age of 1 year -18 to $20 \mathrm{~kg}$. Average carcass yield in early-maturing meat breeds of sheep reaches $65-$ $70 \%$, in fine-wool breeds $-35-40$, other breeds $45-50 \%$.

In the research process we have studied the meat yield of young ewes (table 5).

Table 5 - Main indicators of meat productivity of young ewes

\begin{tabular}{|l|c|c|}
\hline \multirow{2}{*}{ Indicator } & \multicolumn{2}{|c|}{ Group (n=3) } \\
\cline { 2 - 3 } & \multicolumn{1}{|c|}{ II } \\
\hline \multicolumn{1}{|c|}{1} & 2 & 3 \\
\hline Live weight to hungry extract, $\mathrm{kg}$ & $41.1 \pm 2.42$ & $43.3 \pm 2.11$ \\
\hline Pre-slaughter live weight, $\mathrm{kg}$ & $39.7 \pm 2.11$ & $41.85 \pm 2.12$ \\
\hline Fresh carcass weight, kg & $17.5 \pm 0.72$ & $18.4 \pm 0.51$ \\
\hline Internal fat, kg & $0.87 \pm 0.10$ & $1.1 \pm 0.10$ \\
\hline Slaughter weight, kg & $18.37 \pm 0.60$ & $19.5 \pm 0.81$ \\
\hline Slaughter yield, \% & 46.2 & 46.5 \\
\hline Chilled carcasses weight, $\mathrm{kg}$ & $16.66 \pm 0.45$ & $18.00 \pm 0.35$ \\
\hline
\end{tabular}

Young ewes after hungry extracts had average indicators of pre-slaughter weight, common for the sheep of the experimental group.

Young ewes from the experimental group kept on the diets with added amino acids of lysine and methionine was superior in all indicators the animals from the control group animals. So, their carcasses were $18.4 \mathrm{~kg}$, which is $5.1 \%$ more than of the animals from experimental group.

One of the most important indicators of meat quality is the slaughter yield, which in the experimental group was $46.5 \%$ and in the control group $-46.2 \%$, which is $0.3 \%$ higher.

In determining the meat productivity of animals rather important is the energy value of meat that depends on its chemical composition (moisture, protein, fat, ash). It is known that chemical composition of meat depends on breed, age, sex, level of feeding the animal, and the composition of the diet. Its nutritional value is characterized by the presence of components required for biological synthesis and coating energy costs (table 6).

Table 6. Chemical composition of average samples of meat, \%

\begin{tabular}{|l|c|c|}
\hline \multirow{2}{*}{ Indicator } & \multicolumn{2}{|c|}{ Group (n=3) } \\
\cline { 2 - 3 } & $\mathrm{I}$ & II \\
\hline Moisture & 2 & 3 \\
\hline Dry matter & $68.4 \pm 0.54$ & $32.52 \pm 0.12$ \\
\hline Crude ash & $31.6 \pm 0.54 * *$ & $1.19 \pm 0.04$ \\
\hline Crude protein & $1.38 \pm 0.08$ & $27.34 \pm 0.15$ \\
\hline Fat & $26.19 \pm 0.90^{* *}$ & $3.99 \pm 0.15$ \\
\hline Calcium & $4.03 \pm 0.35$ & $3.54 \pm 0.11$ \\
\hline Phosphorus & $3.92 \pm 0.27$ & $0.51 \pm 0.05$ \\
\hline
\end{tabular}


Analyzing the data of table 6 , it should be noted that the meat of animals from experimental group contained less moisture by $0.92 \%(\mathrm{P}<0.01)$, ash by $0.19 \%(\mathrm{P}<0.01)$, fat by $0.04 \%$, calcium by $0.38 \%(\mathrm{P}<0.05)$ than the meat of animals from control group. Ewes from the control group conceded the ewes from the experimental group in dry matter content in meat by $0.92 \%(\mathrm{P}<0.01)$ and crude protein by $1.15 \%(\mathrm{P}<0.01)$. Difference in phosphorus content in both groups was not established.

Amino acid that make up the protein, determine its biological value (Sadovoy, 2017; Trukhachev, 2016; Trukhachev, 2017). In this regard, it was studied the amino acid composition of meat.

The results of a study of amino acid composition of meat are shown in table 7.

Table 7 Amino acid composition of meat (on original substance), $\mathrm{g} / \mathrm{kg}$

\begin{tabular}{|c|c|c|}
\hline \multirow{2}{*}{ Indicator } & \multicolumn{2}{|c|}{ Group } \\
\hline & Control & Experimental \\
\hline 1 & 2 & 3 \\
\hline \multicolumn{3}{|c|}{ Essential amino acids } \\
\hline Threonine & $11.1 \pm 0.06$ & $12.2 \pm 0.08$ \\
\hline Valine & $9.9 \pm 0.03$ & $10.7 \pm 0.03$ \\
\hline Methionine & $4.0 \pm 0.01$ & $4.7 \pm 0.01$ \\
\hline Isoleucine & $8.4 \pm 0.02$ & $10.2 \pm 0.02$ \\
\hline Leucine & $18.5 \pm 0.04$ & $20.1 \pm 0.03$ \\
\hline Phenylalanine & $10.0 \pm 0.03$ & $12.5 \pm 0.03$ \\
\hline Lysine & $19.9 \pm 0.05$ & $21.6 \pm 0.05$ \\
\hline Total & $81.8 \pm 0.22$ & $92.0 \pm 0.22$ \\
\hline \multicolumn{3}{|c|}{ Non-Essential Amino Acids } \\
\hline Aspartic Acid & $\begin{array}{r}19.9 \pm 0.04 \\
\end{array}$ & $20.0 \pm 0.03$ \\
\hline Serine & $10.5 \pm 0.03$ & $11.5 \pm 0.03$ \\
\hline Glutamic Acid & $25.9 \pm 0.05$ & $28.0 \pm 0.04$ \\
\hline Glycine & $10.0 \pm 0.01$ & $11.8 \pm 0.01$ \\
\hline Alanine & $10.4 \pm 0.03$ & $12.7 \pm 0.02$ \\
\hline Tyrosine & $8.9 \pm 0.03$ & $10.3 \pm 0.03$ \\
\hline Histidine & $9.0 \pm 0.03$ & $10.9 \pm 0.03$ \\
\hline Arginine & $18.0 \pm 0.07$ & $20.5 \pm 0.08$ \\
\hline Total & $112.6 \pm 0.26$ & $125.7 \pm 0.26$ \\
\hline Total amino acids & $194.4 \pm 0.48$ & $217.7 \pm 0.48$ \\
\hline Ratio of essential amino acids to non-essential & 0.72 & 0.74 \\
\hline
\end{tabular}

According to the obtaned data it should be noted that in the meat of experimental animals, the amount of amino acids contains $217,7 \mathrm{~g} / \mathrm{kg}$ vs $194.4 \mathrm{~g} / \mathrm{kg}$ of the control group or $19.8 \%(\mathrm{P}<0.001)$ higher in favor of the experimental group.

Leading role for any living organism play such essential amino acids as threonine, methionine, isoleucine, leucine, lysine, which synthesis is restricted in the human body and must come from food.

So, in the meat of experimental animals, threonine contained more than $1.1 \mathrm{~g} / \mathrm{kg}$, or $9.9 \%(\mathrm{P}<0.05)$, methionine $-0.7 \mathrm{~g} / \mathrm{kg}$, or $17.5 \%(\mathrm{P}<0.001)$, isoleucine $1.8 \mathrm{~g} / \mathrm{kg}$, or $24.1 \%(\mathrm{P}<0.001)$, leucine $-1.6 \mathrm{~g} / \mathrm{kg}$, or $8.6 \%(\mathrm{P}<0.001)$, lysine $-1.7 \mathrm{~g} / \mathrm{kg}$, or $8.5 \%(\mathrm{P}<0.001)$, than in animals of the control group.

\section{CONCLUSIONS}

On the basis of the conducted research we made the following conclusions:

1. The content of free amino acids in plasma is directly dependent on their supplying from feed, the amount of free amino acids in the blood of the lambs subject to significant fluctuations. The use of synthetic amino acids (lysine, methionine and cystitis) contributed to the increase of their content in a free state in the serum, which indicates the growing demand of sheep. In particular, when increasing the proportion of lysine in the diet $(1-3$ experimental group) the amount in the blood plasma increased on - 17.55-24.20\%. In the presence of cystine and methionine clear pattern in the increase or decrease in this case could not be traced.

2. One of the most important indicators of the productivity of fine-wool sheep is their wool yield. The wool productivity of the experimental group was higher by $7.8 \%(\mathrm{P}<0.05)$. The increase in wool yield was due to more intensive wool growth in length and increase in diameter due to additional supplements of lysine and methionine with cystine.

3. According to our research, adding different doses of synthetic amino acids (lysine, methionine and cystitis) in the rations of young sheep, we found that supplying optimum conditions of feeding, care and maintenance in unfavorable for sheep winter season, it is possible to avoid abrupt changes in the structure of their skin, to ensure the normal development of the histological structure and morphogenetic processes.

\section{REFERENCES}

1. Abu Fadel, S. 2004. Productivity of young meat-wool sheep under different levels and sources of protein in the diet. Research report Russian university of friendship of people. 
2. Ismailov, I. 1968. Effect of supplementation with synthetic amino acids on the content of free amino acids in a protein-free filtrate of sheep blood. Journal of Bulletin of Agricultural Science, Vol. 3, pp. 143-146.

3. Ismailov, I., Zhukov, L., Chabaev, I. 1991. Use in diets of calves of synthetic amino acids and protein green concentrate: recommendations, Stavropol book publishing house, Stavropol.

4. Sadovoy, V., Selimov, M., Slichedrina, T., Nagdalian, A. 2016. Usage of biological active supplements in technology of prophilactic meat products. Research Journal of Pharmaceutical, Biological and Chemical Sciences, Vol. 7, Iss. 5, pp. $1861-1865$.

5. Selkin, I., Kochkarov, R. 2011. Wool productivity of sapling of masochistic sheep. Journal of Husbandry, Vol. 4, pp. 24-25.

6. Tregubova, N., Ismailov, I., Tkachenko, M. 2016. Interrelation of prooksidantno-antioksidantnoy of system with efficiency of farm animals. Journal of APC Bulletin Stavropol, Vol. 3, No. 23, pp. 116-120.

7. Trukhachev, V., Zlidnev, N. 2008. A requirement of highly productive fine-fleece sheep is in amino acids. Research-production Journal of Sheep, Goat and Woolen Business, Vol. 3, pp. 48-49.

8. Trukhachev, V., Zlidnev, N., Podkolzin A.2009. Feeding of farm animals in the North Caucasus. Stavropol book publishing house, Stavropol.

9. Trukhachev, V., Moroz, V., Chernobay, E., Ismailov, I. 2016. Meat and interior features rams of different genotypes. Research Journal of Pharmaceutical, Biological and Chemical Sciences, Vol. 7(1), pp. 1626-1630.

10. Trukhachev, V., Oliinyk, S., Zlidnev, N. 2017. Creation of optimal selection-technological model cow of production type based on holstein genotype. Proceedings of the International Sciences Conference Rural Development 2017, pp. 916-919, Latvia Academy of Agricultural and Forest Sciences. 